\title{
Aedes Mosquitoes and Aedes-Borne Arboviruses in Africa: Current and Future Threats
}

\author{
David Weetman $^{1}$, Basile Kamgang ${ }^{2}$ (D), Athanase Badolo ${ }^{3}$ (D), Catherine L. Moyes ${ }^{4}$ (D), \\ Freya M. Shearer ${ }^{4}$, Mamadou Coulibaly ${ }^{5}$, João Pinto ${ }^{6}$ (D), Louis Lambrechts ${ }^{7,8}$ (iD and \\ Philip J. McCall 1,* (D)
}

1 Department of Vector Biology, Liverpool School of Tropical Medicine, Pembroke Place, Liverpool L3 5QA, UK; david.weetman@lstmed.ac.uk

2 Centre for Research in Infectious Diseases, Yaoundé PO Box 13501, Cameroon; kamgang_d@yahoo.fr

3 Laboratoire d'Entomologie Fondamentale et Appliquée (LEFA), Université Ouaga 1 Pr Joseph Ki-Zerbo, Ouagadougou 03 BP 7021, Burkina Faso; a.badolo@gmail.com

4 Big Data Institute, Li Ka Shing Centre for Health Information and Discovery, University of Oxford, Oxford OX3 +7LF, UK; clmoyes@well.ox.ac.uk (C.L.M.); freya.m.shearer@gmail.com (F.M.S.)

5 University of Sciences, Techniques and Technologies of Bamako, Bamako BP 1805, Mali; doudou@icermali.org

6 Global Health and Tropical Medicine (GHTM), Instituto de Higiene e Medicina Tropical (IHMT), Universidade Nova de Lisboa (UNL), Rua da Junqueira 100, 1349-008 Lisbon, Portugal; JPinto@ihmt.unl.pt

7 Insect-Virus Interactions, Department of Genomes and Genetics, Institut Pasteur, 75015 Paris, France; louis.lambrechts@pasteur.fr

8 Centre National de la Recherche Scientifique, Unité Mixte de Recherche 2000, 75015 Paris, France

* Correspondence: philip.mccall@lstmed.ac.uk; Tel.: +44-151-705-3132

Received: 12 December 2017; Accepted: 24 January 2018; Published: 28 January 2018

\begin{abstract}
The Zika crisis drew attention to the long-overlooked problem of arboviruses transmitted by Aedes mosquitoes in Africa. Yellow fever, dengue, chikungunya and Zika are poorly controlled in Africa and often go unrecognized. However, to combat these diseases, both in Africa and worldwide, it is crucial that this situation changes. Here, we review available data on the distribution of each disease in Africa, their Aedes vectors, transmission potential, and challenges and opportunities for Aedes control. Data on disease and vector ranges are sparse, and consequently maps of risk are uncertain. Issues such as genetic and ecological diversity, and opportunities for integration with malaria control, are primarily African; others such as ever-increasing urbanization, insecticide resistance and lack of evidence for most control-interventions reflect problems throughout the tropics. We identify key knowledge gaps and future research areas, and in particular, highlight the need to improve knowledge of the distributions of disease and major vectors, insecticide resistance, and to develop specific plans and capacity for arboviral disease surveillance, prevention and outbreak responses.
\end{abstract}

Keywords: Aedes aegypti; Aedes albopictus; Aedes formosus; Zika; dengue; chikungunya; yellow fever; vector

\section{Introduction and Overview}

The crisis following the Zika epidemic across South America in 2015-2016 and the newly recognised severe neurological consequences of infection have raised global awareness of Aedes-borne arboviral diseases. Zika has also belatedly turned the scientific community's attention to Africa, where this virus was originally identified [1] and where the other Aedes-transmitted arboviruses also occur. Despite its global importance [2], the extent of the dengue burden in Africa remains unknown [3], as does the true burden of yellow fever, though tens of thousands die annually in Africa and the threat 
of outbreaks remains high [4,5], even with availability of an effective vaccine [6]. Moreover, the risk of exporting yellow fever from Africa remains a concern, particularly to immunologically naïve Asian populations $[7,8]$.

Why was so little attention paid to Aedes-borne arboviruses in Africa, until they led to outbreaks in locations outside of Africa? One explanation is that these viruses constitute greater public health threats for immunologically-naïve non-African human populations. A second is that the magnitude of the burden of malaria and many neglected tropical diseases in Africa detract attention from Aedes-borne infections. A third and related factor is that accurate identification of arboviral infections in resource-poor settings is challenging, and in Africa, many fevers of unknown origin tend to be recorded as malaria [7]. Hence, the major arboviral infections remain neglected in Africa, while receiving significant attention and resources for control elsewhere.

In common with Zika [8], chikungunya [9], yellow fever [10], and perhaps also dengue [11], Aedes aegypti almost certainly originated in Africa [12-14]. Globally Ae. aegypti is the primary vector of all of these viruses, but a range of African Aedes species are competent and epidemiologically-significant vectors. An important addition to this vector fauna is Aedes albopictus, introduced into Africa less than 30 years ago and still increasing its range [15].

Adaptation of arboviruses to novel vectors can occur rapidly and can have significant consequences. A single amino acid substitution facilitated efficient transmission of the chikungunya virus by Ae. albopictus [16], permitting establishment of local transmission in many new regions beyond Africa, following the 2005-2006 outbreak on the island of La Réunion. Simple genetic changes can also affect the virus's interaction with the vertebrate host, with uncertain but potentially severe consequences [17]. The Zika virus also can be transmitted through sexual intercourse, though the epidemiological importance of this mode of transmission remains to be determined [18].

Control of Zika and other Aedes-transmitted arboviruses is a major 21st century challenge for global public health, exacerbated by widespread insecticide resistance in the vectors [19] and a relentless growth in urban environments [20]. This is especially true in the resource-poor sub-Saharan nations, which have the lowest collective Gross Domestic Product (GDP) of any region [21]. A thorough exploration of the burden, transmission biology and control of Aedes-transmitted arboviruses is essential to define, understand and prepare for potential future threats in Africa and worldwide [22,23]. Here, we review current information on these key topics for Aedes vectors and the major arboviruses they transmit in Africa, highlighting knowledge gaps, and recommending priorities for further investigation.

\section{The Burden of Aedes-Borne Viral Diseases in Africa}

The extent of chikungunya, dengue and Zika virus distributions in Africa is largely unknown, and our knowledge of the variation in transmission risk within these zones, as well as within the yellow fever risk zone [6], is hampered by a lack of disease data. Ecological models have been used to estimate the spatial distributions of each virus [2,24-26], and we have used these maps to generate comparable estimates for the population at risk of infection (PAR) (Supplementary Materials). Table 1 shows the estimated African PAR for chikungunya, dengue, yellow fever and Zika [24-28]. The value for yellow fever was adjusted to take account of vaccination campaigns conducted in parts of Africa and shows the much lower PAR for this disease since vaccination began [29]. Individual disease distributions overlap (Figure 1), and an estimated 831 million people were living in an area at risk of at least one of these arbovirus infections in 2015 (Table 1). However, these estimates are based on predicted distributions within unknown disease ranges: actual PAR values cannot be estimated with certainty until the extent of each disease has been defined and more case data are collected across the continent. Furthermore, the number of people living in an area of risk who are actually protected by life-long immunity conferred by previous infection with the chikungunya virus, Zika virus and each serotype of the dengue virus is unknown but could change the PAR figures dramatically [30-32]. Outbreaks of all four diseases are characterised by large spikes in the number of cases, often preceded 
and followed by periods when no new cases are reported [33]. Therefore, the values shown (Table 1 and Figure 1) represent the presence of a transmission risk at some point in time over a number of years, rather than a year-round or seasonal risk. As the uncertainty in the PAR highlights, there is an urgent need to improve data availability and quality in order to map more accurately the disease burden in Africa.

Table 1. Estimated population at risk of infection (PAR) by each arbovirus and by overlapping arboviruses in Africa, 2015. Population estimates were calculated using the methods and data sources as defined and cited in Figure 1a,b, respectively.

\begin{tabular}{ccc}
\hline Infection & Estimated Population at Risk & Percentage of African Population \\
\hline Chikungunya & 271 million & $23 \%$ \\
Dengue & 750 million & $63 \%$ \\
Yellow fever & 21 million & $2 \%$ \\
Zika & 406 million & $34 \%$ \\
At least one of the above & 831 million & $70 \%$ \\
\hline
\end{tabular}

* The value for yellow fever has been adjusted to account for reductions in the population at risk following vaccination programmes.
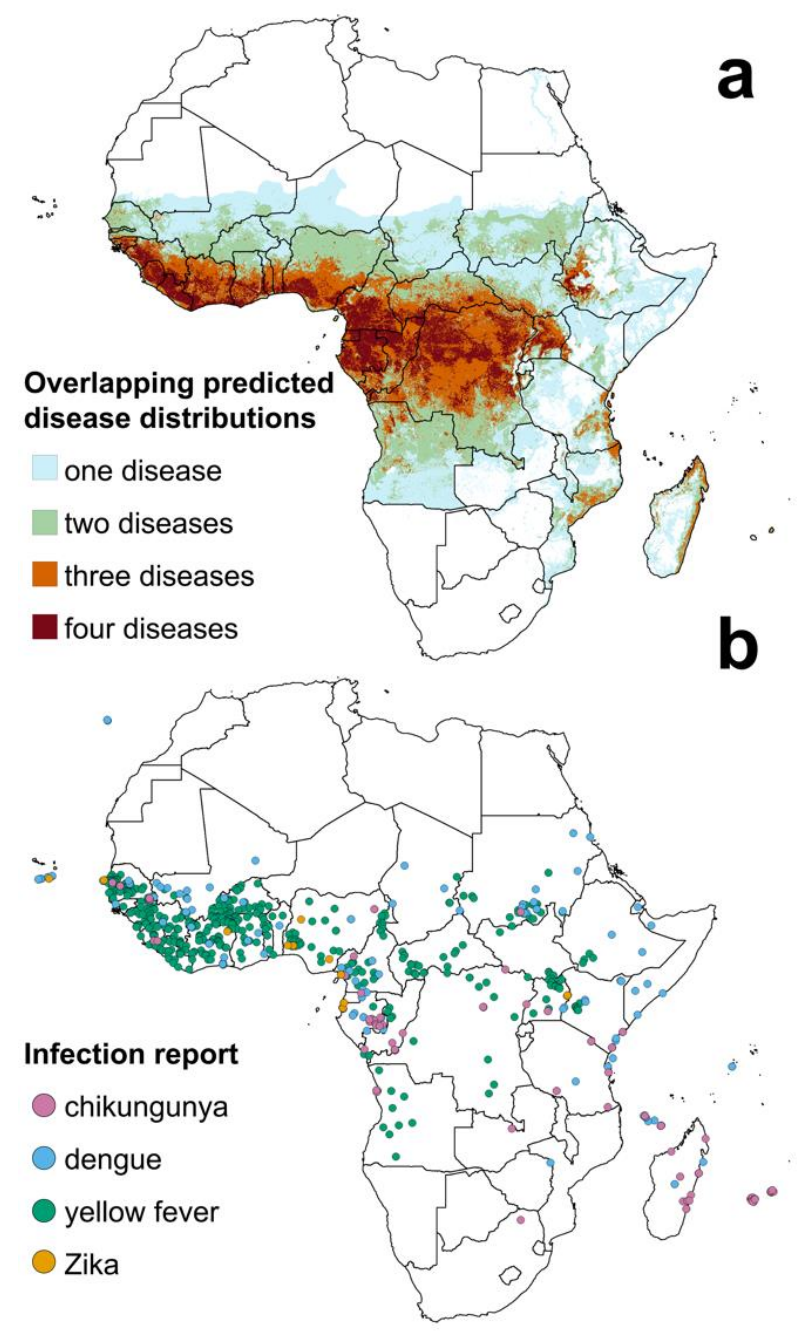

Figure 1. The distributions of chikungunya, dengue, yellow fever and Zika virus infections in humans in Africa. (a) Areas at risk of one, two, three or all four infections; map generated as described in Supplementary Methods. (b) Locations of reported infections (symptomatic and non-symptomatic) of dengue, chikungunya, Zika and yellow fever [24-28]. 


\section{Range and Distribution of Aedes Vector Species in Africa}

African ranges are unknown, even for the two major Aedes vector species, and there are insufficient records to allow their definition either by expert opinion or any semi-quantitative method. Suitable environments for Ae. albopictus and Ae. aegypti within Africa have been predicted using ecological models (Figure 2) [34], and though the maps indicate extensive areas of suitability and a large potential for sympatric occurrence, these estimated distributions need to be treated with caution. Maps show locations where the species could potentially occur but not necessarily where they have been found. For example, much of sub-Saharan Africa is predicted to be suitable for Ae. albopictus, but records remain patchy [35-64]. Since the worldwide records of each species were compiled, new studies in Africa have reported Ae. aegypti in Ghana [51], Mozambique [55] and Namibia [59], and Ae. albopictus in Mali [57], Morocco [39], Mozambique [50] and São Tomé and Príncipe [62].

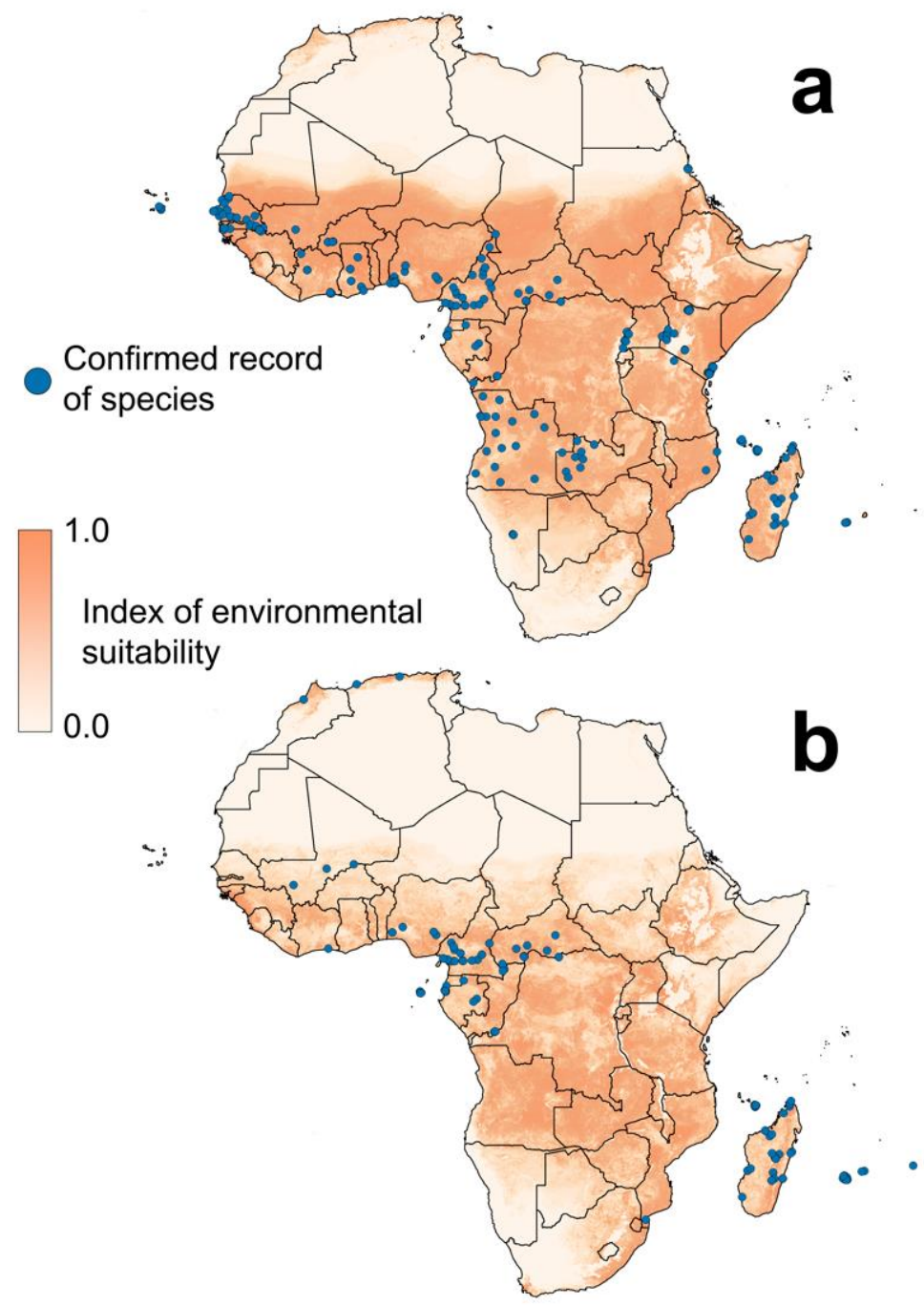

Figure 2. Reports of mosquito occurrence and areas of predicted environmental suitability for Aedes albopictus and Ae. aegypti in Africa [36-64]: (a) Ae. aegypti; (b) Ae. albopictus.

The areas of predicted suitability shown in Figure 2 are based on relationships with environmental and socio-economic variables. Studies using global records of each species found that temperature is the most influential predictor and that precipitation, vegetation indices and urban land cover also play a role $[33,65]$. Few studies have looked at these relationships in African populations, but temperature is still likely to be important [66,67] and rainfall is strongly linked to Aedes vector abundance in Kenyan 
populations [68]. Specific landscape factors are more likely to vary between different regions of the world and the influence of some of these have been studied in African locations. In Central Africa, Ae. albopictus preferred man-made breeding sites (tyres and tanks) surrounded by vegetation whereas Ae. aegypti preferred man-made breeding sites in neighbourhoods with higher building density $[69,70]$. Similarly, in urban Cameroon, Ae. aegypti was more abundant in downtown environments in the dry season whereas Ae. albopictus was more prevalent in the suburbs in all seasons [71]. Studies in rural areas have found that within oil palm-dominated landscapes in Côte d'Ivoire Ae. aegypti was more abundant in polycultures than monocultures [72].

Large gaps in reporting of each species can be seen in Figure 2, but vector presence can be inferred from reports of locally acquired arbovirus infections (Figure 1b). These case reports show infections occurring in a number of countries where no vector data are available, implying that one of more of the arbovirus vectors is present. Which vectors might be found in these locations can only be addressed by field surveys, and priority should be given to the countries reporting arbovirus infections but no recent reports or records of vector species. Currently these are Guinea, Guinea Bissau, Sierra Leone, Liberia, Togo, Chad, South Sudan, Ethiopia, Eritrea, Djibouti, Somalia.

\section{Vectorial Capacity of Different Aedes Species in Africa}

\subsection{Aedes aegypti vs. Aedes albopictus}

Aedes aegypti is considered the main vector of dengue viruses worldwide, largely attributable to its higher vector competence and stronger host preference for humans compared to Ae. albopictus [73]. However, Ae. albopictus has been a driving force in the worldwide emergence of chikungunya virus since 2004 [74], and in Central Africa it is considered to have played a key role in the 2007 emergence of dengue, chikungunya [75,76] and possibly Zika [77]. Moreover, its ongoing range expansion across Africa has the potential to increase the arbovirus transmission risk to areas far from urbanisation [78]. Improved knowledge of Ae. albopictus distribution and vectorial capacity in Africa is required to enhance arbovirus surveillance and prevention [79].

\subsection{Sylvatic vs. Domestic Forms of Aedes aegypti}

Aedes aegypti is believed to have originated in Africa from a generalist, zoophilic tree-hole breeder [12]. Outside Africa, Ae. aegypti populations are exclusively found in close association with humans in the domestic environment, and this domestic form of Ae. aegypti may have originated from a population that adapted to (i) breeding in artificial water storage containers and (ii) biting humans [80]. Domestication events involving human-feeding specialization may have occurred both outside Africa as part of the species' expansion, and within Africa [81], possibly, but perhaps not exclusively, on the West African coast [82].

African Ae. aegypti breed in both the domestic environment and in the ancestral sylvatic habitat. Whereas domestic Ae. aegypti larvae develop in artificial containers (e.g., tyres, discarded containers, jars, flower pots, metal drums) within or in close proximity to human habitation, larvae of the sylvatic ecotype are found in natural breeding sites (e.g., rock pools, tree holes, plant axils, fruit husks) in forested areas [80]. Interestingly, larvae of the two Ae. aegypti ecotypes are exposed to different bacterial communities in their respective breeding sites, potentially resulting in differences in vectorial capacity [83]. Classically, two morphological subspecies were described in Africa that broadly correspond with these ecotypes: Ae. aegypti aegypti and Ae. aegypti formosus. However, there is evidence that Ae. aegypti formosus is increasingly found in urban environments [84], and the diagnostic morphological characters (presence/absence of white abdominal scaling patterns [85]) often form a continuum [86]. Similarly, clear genetic boundaries are absent, presumably as a result of extensive current or recent historical gene flow $[87,88]$. The picture may be complicated further by introductions of domestic Ae. aegypti into Africa and interbreeding with local populations $[89,90]$. The result is a lack of clear correlation between morphology, genetics and ecology [81,90,91], which calls into question 
the utility of the simple division of the diverse African Ae. aegypti fauna into the aegypti and formosus subspecies $[80,84]$.

African Ae. aegypti have traditionally been considered less competent for flaviviruses than Ae. aegypti from the rest of the world [92,93]. A global survey of 28 populations found that sylvatic Ae. aegypti populations from West Africa were the least susceptible to yellow fever virus infection [94]. However, more recent observations indicated that vector competence of African Ae. aegypti is extremely variable and depends on specific pairings of mosquito population and viral isolate [76,95-98]. Such genotype-by-genotype specificity has been widely documented in other host-pathogen systems [99].

\subsection{Other Aedes Species and Potential for Emergent Transmission Cycles}

Additional Aedes species play a critical role in arbovirus transmission cycles in Africa because (i) they are involved in sylvatic arbovirus transmission cycles and/or (ii) they bridge sylvatic and human transmission cycles. For example, Aedes africanus is considered the main sylvatic vector of yellow fever virus in Africa [100] and can also act as a bridge vector to humans, together with Aedes bromeliae, Aedes furcifer, Aedes taylori, Aedes luteocephalus, Aedes metallicus, Aedes opok, Aedes vittatus, and species of the Aedes simpsoni complex [101]. Sylvatic dengue viruses in Africa are transmitted among non-human primates by Ae. furcifer and Ae. luteocephalus, and usually cross over to humans through biting by Ae. furcifer [101]. Bridge vectors may initiate a human outbreak, but large epidemics typically occur only when virus transmission involves urban populations of Ae. aegypti or Ae. albopictus, though there may have been exceptions: Haddow [102] described Ae. simpsoni (=Ae. bromeliae [15]) as being "the principal vector in the greatest known African yellow fever epidemic", which occurred in Ethiopia in the early 1960s.

The majority of these Aedes vector species are found in rural or forest areas, and so are less likely to present a threat in the urban environments where Ae. aegypti populations thrive. Nonetheless, increasing erosion of their natural habitats could lead to greater contact with humans, and/or formerly obligate sylvatic species might adapt to new urban environments and hosts, potentially with a greater role as vectors [103]. Many readily feed on both domestic and wild animals including primates, as well as humans, hence their potential importance as bridging vectors [96,104-106]. Although a sylvatic dengue transmission cycle is known in restricted locations like eastern Senegal $[107,108]$, it is unclear how important it is across the continent of Africa. All of the focal arboviral diseases circulate among non-human primates in Africa, though the true role of animal reservoirs in the epidemiology of human disease remains to be determined [109].

Less is known about the African vectors of Zika, and although multiple Aedes species from across Africa have been found naturally infected with the Zika virus, this is also true for non-Aedes species, and cannot be translated into vector competence [110,111]. In a rare demonstration, a small proportion of Ae. vittatus and Ae. luteocephalus were found to harbour the virus in their salivary glands following artificial infection with Zika strains, suggesting some potential for transmission [110]. With a growing body of evidence from elsewhere showing the Zika virus' capacity for development and transmission by species in addition to Ae. aegypti and Ae. albopictus [112], further studies to test competence in the African vectors from which it has been isolated should be prioritised.

Better knowledge of African transmission cycles is important to determine the risk of viruses like Zika or chikungunya establishing similar sylvatic cycles in geographic regions where they have newly arrived $[113,114]$. Recent reports from Kenya suggest that human infections may be a source of 'spillback' infections in baboon populations [85], demonstrating the range of potential consequences following introduction of novel viruses or strains. Clearly, assessing the risk of human infection by arboviruses will require more in-depth studies on the biology of sylvatic Aedes spp. in Africa [104,107]. 


\section{Vector Surveillance and Control of Aedes species in Africa}

The majority of Aedes spp. control studies have focused on dengue outbreaks in urban sites in Asia or Latin America, where transmission by Ae. aegypti and/or Ae. albopictus is exclusively human to human $[115,116]$. Indeed, a recent systematic review of the evidence for effectiveness of vector control in reducing dengue virus transmission included 41 trials, but none were from Africa [117].

The widespread use of the insecticide DDT (dichlorodiphenyltrichloroethane) in Ae. aegypti eradication programmes, that led to its near elimination from South America by the late 1960s, was never replicated in Africa $[4,118]$. Subsequently, factors such as increased international freight and travel, urbanization, and vector control strategies and tools poorly suited to urban environments or hampered by insecticide resistance [119] have resulted in the global explosion of dengue. Yellow fever outbreaks can be prevented or controlled by mass vaccine distribution [120], but no vaccines are available for chikungunya and Zika, and the licensed dengue vaccine offers incomplete and serotype-specific protection [121]. Consequently, outbreak prevention and response remain reliant on vector control.

Preventing outbreaks, or mitigating their impact, is challenging even for those countries that have made considerable investment in capacity after fighting against dengue outbreaks for decades [122]. This scenario and the associated challenges are exacerbated in African countries where recognition of dengue outbreaks has started relatively recently; dengue is often not a reported infection, even if correctly diagnosed, and where surveillance and response strategies may be absent or improperly developed [123-126]. Rolling out effective surveillance plans for Aedes-borne diseases, particularly dengue, is a global priority $[127,128]$ but at present, early warning systems for Aedes-borne diseases like dengue are unreliable [129], and the standard indices used to monitor Ae. aegypti populations are inaccurate [130].

\subsection{Integrating Aedes Species Control with Malaria Vector Control: Uniquely African Opportunities?}

Malaria cases and deaths have declined in Africa since 2000 but sustaining control toward elimination remains a major focus for African healthcare [131]. Vector control has played a central role, primarily via long-lasting insecticide treated nets (LLINs) and indoor residual spraying (IRS) [132], and this is likely to continue. What opportunities might recognition of the importance of vector control for both malaria and Aedes-borne arboviruses offer in Africa? Some interventions targeting African malaria vectors are unlikely to have a significant impact on Aedes-borne arboviral transmission because of differences in their biology. For example, LLINs primarily target nocturnal biters and zooprophylaxis targets domestic animal-biters, neither of which typically apply to Ae. aegypti [133,134], though the latter may be of some relevance to the more generalist feeder Ae. albopictus [135]. However, IRS targets indoor resting; a behaviour common not only to malaria vectors like Anopheles gambiae and An. funestus, but also to Ae aegypti [133,136-138]. Results to date are promising [117,139-141], but to be effective across the target species, IRS will require careful consideration of available insecticides because in both An. gambiae and Ae. aegypti, resistance (see Section 5.2) can lead to operational IRS failure [140,142]. House screening [143] and other improvements which prevent mosquito entry [144,145] might be effective against both Anopheles malaria vectors and Ae. aegypti, although perhaps less so against the more exophilic Ae. albopictus.

Larval source management can be effective individually for both malaria [146] and dengue [117] but its potential as a cross-cutting intervention is limited owing to the typically different breeding sites of Anopheles and Aedes. Larval stages of Anopheles are usually found in ground pools or irrigated sites, especially rice paddies, while Aedes proliferate in manmade containers or small natural sites such as rock pools and tree holes. Nevertheless, biological and chemical larviciding formulations, such as Bti and pyriproxyfen, represent important tools in the arsenal for control of Aedes larvae $[147,148]$ and in some settings, they may also be appropriate for Anopheles control [149,150], potentially offering logistical and procurement synergies. 
There is currently little evidence to suggest efficacy of personal repellents for control of either dengue or malaria [117,151-153]. Though promising for both Anopheles and Aedes vector control [154,155], demonstration of the impact of volatile spatial insecticides on epidemiological indicators is currently lacking for malaria or arboviruses. Similarly, attractive toxic sugar baits (ATSB) might eventually prove to be effective against different diseases, although at present it is unclear whether the same bait will attract both Aedes and Anopheles species, whilst avoiding negative impacts of traps on economically-beneficial insects [156].

The control of Aedes spp. in Africa could benefit from association with already well-established national malaria control programmes. This is in line with the first pillar of the global vector control response developed by the World Health Organisation (WHO) that calls for strengthening inter- and intra-sectoral action and collaboration [157]. Following identification of disease overlaps [158] and control opportunities [61], provision of training will be a key issue to ensure that experienced malaria vector control practitioners become effective arboviral disease vector controllers. In addition, funding agreements will have to be reached to avoid diversion of resources from malaria programmes where the perceived current disease risk may be relatively low in elimination or pre-elimination settings, resources for which in many cases, are already inadequate to maintain a consistent downward malaria trajectory [137].

\subsection{Insecticide Resistance and Challenges to Control}

Worldwide data on insecticide resistance in Ae. aegypti and Ae. albopictus are patchy, with by far the majority of data originating from Latin America and South-East Asia [19]. This paucity is readily evident in Africa, with just 18 published studies, of which three $[44,64,159]$ were conducted over 30 years ago. The remainder involve WHO tube and larval bioassays on samples collected within the last ten years from 12 countries (Table 2).

DDT resistance is widespread and has been reported from every country tested, and in both Ae. aegypti and Ae. albopictus. Resistance to pyrethroids (primarily permethrin and deltamethrin) appears more sporadic but there are confirmed reports in Ae. aegypti from mainland West, Central and East Africa. It should also be noted that An. gambiae doses are almost always used for assessment of pyrethroids and may underestimate resistance because Ae. aegypti discriminant doses are lower [160]. Pyrethroid resistance may currently be less critical than in South East Asia and Latin America [19], but in Africa appears to be emergent, and is not limited to particular regions.

Organophosphate adulticides (malathion or fenitrothion) have been less frequently tested but only in Madeira and Sudan has resistance been confirmed in Ae. aegypti. All studies from West Africa and islands testing carbamates (usually propoxur) have reported resistance. Studies from other areas have typically reported susceptibility, but very recent testing in Yaoundé, Cameroon, detected bendiocarb resistance in both Ae. aegypti and Ae. albopictus [71], suggesting that apparent geographical patterns may be a consequence of the limited number of studies performed to date.

Fortunately, tests of the first-line biological and chemical larvicides, Bti and temephos, have not detected a problematic level of resistance. In dose-response assays the highest resistance ratios (calculated from the ratio of the lethal concentration killing 50\% of the test, compared to a susceptible reference strain) are from Cape Verde and suggest little resistance [161]. 
Table 2. Records of insecticide resistance in Aedes species (1990 onwards) from African mainland countries and islands. Resistance is classified according to WHO standards as resistant (R) < 90\% mortality, suspected resistance (RS) 90-97\% mortality, or susceptible (S) > 97\% mortality in adult (a) tube or larval (l) bioassays. Brief details of resistance mechanisms are shown where reported. Studies are ordered by species, then from North-West toward South-East. Blank cells indicate that the phenotype or mechanism was not investigated.

\begin{tabular}{|c|c|c|c|c|c|c|c|c|c|c|c|c|c|c|}
\hline Study & Year & Country & Area & Species & DDT (a) & Pyr I (a) & Pyr II (a) & Carb (a) & $\mathrm{OP}(\mathrm{a})$ & $\begin{array}{c}\text { Temephos } \\
\text { (1) }\end{array}$ & $B t i(1)$ & Other (1) & $\begin{array}{c}k d r \\
\text { Mutations }\end{array}$ & Metabolic Resistance \\
\hline [162] & 2013 & Madeira & $\begin{array}{l}\text { Funchal, Paul } \\
\text { do Mar }\end{array}$ & Ae. aegypti & & $\mathrm{R}$ & $\mathrm{R}$ & $\mathrm{R}$ & $\mathrm{R}, \mathrm{S}$ & & & & $\begin{array}{l}\text { F1534C; } \\
\text { V1016I }\end{array}$ & $\begin{array}{l}\text { MFO, esterases (biochemistry); PBO, } \\
\text { DEM significant (synergist; } \\
\text { metabolizing genes overexpressed) }\end{array}$ \\
\hline$[43]$ & 2009 & Cape Verde & Santiago & Ae. aegypti & $\mathrm{R}$ & $\mathrm{s}$ & $\mathrm{s}$ & $\mathrm{R}$ & $\mathrm{s}$ & & & & & \\
\hline [163] & 2012 & Cape Verde & $\begin{array}{l}\text { Santiago, } \\
\text { Praia }\end{array}$ & Ae. aegypti & & & $\mathrm{R}$ & & s & S & & & Not detected & MFO, esterases, GSTs (biochemistry) \\
\hline$[63]$ & 2009 & Senegal & Dakar & Ae. aegypti & $\mathrm{R}$ & S & R, RS & $\mathrm{R}$ & $\mathrm{s}$ & & & & & \\
\hline [52] & 2010 & Côte d'Ivoire & Abidjan & Ae. aegypti & & $\mathrm{s}$ & $\mathrm{RS}, \mathrm{S}$ & $\mathrm{R}, \mathrm{RS}$ & & & & & & \\
\hline [46] & 2014 & Côte d'Ivoire & Abidjan & Ae. aegypti & $\mathrm{R}$ & $\mathrm{s}$ & RS & RS & & & & S (DDT, Pyr) & & \\
\hline [164] & 2012-2013 & Ghana & Accra & Ae. aegypti & $\mathrm{R}$ & $\mathrm{R}$ & $\mathrm{R}$ & & & & & & & \\
\hline$[51]$ & 2013-2014 & Ghana & Widespread & Ae. aegypti & $\mathrm{R}$ & $\mathrm{R}, \mathrm{RS}, \mathrm{S}$ & & & & & & & $\begin{array}{l}\text { F1534C; } \\
\text { V1016I }\end{array}$ & \\
\hline$[51]$ & 2013-2014 & Ghana & Widespread & $\begin{array}{l}\text { Aedes aedes } \\
\text { formosus }\end{array}$ & $\mathrm{R}$ & $\mathrm{R}, \mathrm{RS}, \mathrm{S}$ & & & & & & & F1534C & \\
\hline [37] & 2011-2012 & Nigeria & Lagos & Ae. aegypti & $\mathrm{R}$ & $\mathrm{s}$ & $\mathrm{RS}, \mathrm{S}$ & & & & & & & \\
\hline [60] & 2013 & Nigeria & Kwara State & Ae. aegypti & $\mathrm{s}$ & $\mathrm{S}$ & & $\mathrm{R}$ & & & & & & \\
\hline [49] & 2007 & Cameroon & Widespread & Ae. aegypti & RS & & $\mathrm{s}$ & $\mathrm{s}$ & $\mathrm{s}$ & $\mathrm{s}$ & S & & & \\
\hline [71] & 2015-2016 & Cameroon & Yaoundé & Ae. aegypti & $\mathrm{R}$ & $\mathrm{s}$ & $\mathrm{R}$ & $R, S$ & $\mathrm{~s}$ & & & & Not detected & Limited effect of synergist PBO \\
\hline$[58]$ & 2013 & $\begin{array}{c}\text { Central } \\
\text { African Rep. }\end{array}$ & Bangui & Ae. aegypti & $\mathrm{R}, \mathrm{RS}$ & & $\mathrm{RS}, \mathrm{S}$ & s & s & s & s & & Not detected & MFO, esterases, GSTs (biochemistry) \\
\hline [49] & 2007 & Gabon & Libreville & Ae. aegypti & $\mathrm{R}$ & & $\mathrm{s}$ & $\mathrm{s}$ & s & s & $\mathrm{s}$ & & & \\
\hline$[48]$ & 2009,2010 & Sudan & Port Sudan & Ae. aegypti & $\mathrm{R}$ & & $\mathrm{RS}, \mathrm{S}$ & S & $\mathrm{R}, \mathrm{RS}$ & & & & & \\
\hline [165] & 2015 & Tanzania & Dar es Salaam & Ae. aegypti & & $\mathrm{R}, \mathrm{RS}$ & $\mathrm{R}, \mathrm{RS}$ & & & & & & & \\
\hline [166] & 2010-2011 & Mayotte & Petit Terre & Ae. aegypti & & & $\mathrm{s}$ & & & $\mathrm{s}$ & $\mathrm{s}$ & S (multiple) & & \\
\hline [49] & 2007 & Cameroon & Widespread & Ae. albopictus & $\mathrm{R}$ & & $\mathrm{RS}, \mathrm{S}$ & s & s & s & s & & & \\
\hline$[71]$ & 2015-2016 & Cameroon & Yaounde & Ae. albopictus & $\mathrm{R}$ & $R, S$ & $\mathrm{R}, \mathrm{RS}$ & $\mathrm{R}, \mathrm{RS}$ & S & & & & Not detected & Variable effect of synergist PBO among \\
\hline$[58]$ & 2014 & CAR & Bangui & Ae. albopictus & $\mathrm{R}, \mathrm{RS}, \mathrm{S}$ & & $\mathrm{R}, \mathrm{RS}, \mathrm{S}$ & $\mathrm{RS}, \mathrm{S}$ & $\mathrm{RS}, \mathrm{S}$ & S & S & & Not detected & MFO, esterases, GSTs (biochemistry) \\
\hline$[49]$ & 2007 & Gabon & Libreville & Ae. albopictus & & & & & & $\mathrm{s}$ & & & & \\
\hline [61] & $2010-2011$ & Mayotte & Kaweni & Ae. albopictus & & & $\mathrm{s}$ & & & $\mathrm{s}$ & s & $\mathrm{S}$ (multiple) & & \\
\hline
\end{tabular}

DEM (diethyl maleate); GST (glutathione S-transferase) 
Susceptibility to $B t i$ is expected based on its complex mode of toxicity and lack of any previous reports of resistance in Aedes field populations [19]. In contrast, temephos resistance is extremely common in Latin America and is found throughout Asia [19], yet apparent full susceptibility in Africa allows temephos to be regarded as a viable option for water treatment.

There is currently very limited information on the mechanisms of insecticide resistance in African populations of either key Aedes vector species. Knockdown resistance $(k d r)$ mutations in the voltage-gated sodium channel, which can generate high levels of resistance when present in combinations $[166,167]$, have recently been detected in West Africa, though not to date elsewhere, albeit from very limited investigations (Table 2). High frequencies of F1534C, the only $k d r$ mutation known to show a worldwide distribution [19], have been found in samples from throughout Ghana [51], whilst the Latin American V1016I variant was detected in a single Ghanaian sample. In the absence of target site mutations, evidence for metabolic resistance via efficacy of synergists in bioassays or elevated activity of mixed-function oxidases, esterases and glutathione-S-transferases in biochemical assays has been suggested as at least a partial explanation for some resistant phenotypes (Table 2).

The source of resistance in African Aedes populations is less obvious than for areas of Latin America and Asia subjected to targeted control programmes. Widespread recent use of DDT and pyrethroids for IRS against malaria vectors might be one source; however, introductions, rather than simply in situ selection from local genetic variation, might be important. For example, the 1534C $k d r$ mutation found in Africa is linked to a non-African, presumably immigrant, haplotype [34]. On Madeira, a multiple-insecticide resistant Ae. aegypti population has likely been introduced recently, possibly from Latin America [162], ready-equipped with two $k d r$ mutations and overexpression of multiple pyrethroid metabolising genes $[168,169]$.

In general, the picture of resistance suggests that viable insecticidal options remain available to target African Aedes populations. Yet, the potential for insecticide resistant Ae. aegypti and Ae. albopictus to be imported via human-aided movement of mosquitoes over long distances [170], rather than via slow natural migration, is a major concern, and a challenge to curbing the spread of resistance.

\section{Conclusions}

\section{Major Knowledge Gaps and Recommendations}

Over 60 years ago, and with considerable prescience, Mahaffy [118] argued the case for eradication of Ae. aegypti from Africa, writing: "A successful eradication programme of this nature carries with it results of such profound importance, not only to Africa, but also to infectible territories outside Africa, that it is impossible to over-emphasize the necessity for its initiation at the earliest possible moment". Most would agree that the prospect for elimination of Ae. aegypti from Africa is not a realistic one at present, but that the need to reverse decades of neglect of arboviral disease in Africa is long overdue.

To build an appropriate evidence base on which disease prevention and control strategies and policies can be founded, we recommend the following topics be prioritized for investigation: distribution of cases of dengue, chikungunya, Zika and other arboviruses in humans; distributions of Ae. aegypti and Ae. albopictus in Africa; updated characterization and distribution of insecticide resistance in Ae. aegypti and Ae. albopictus, with broader geographical coverage using standardized methodologies; development of context-specific Aedes-borne arboviral disease surveillance plans, and of outbreak prevention and vector control response strategies.

Integral to the success of the above topics is the need for capacity strengthening in biology, diagnosis and control of arboviral disease vectors in all African nations under threat from these infections.

Additional topics or knowledge gaps that merit investigation should include the following: controlled trials of vector interventions in African settings; the pros and cons of developing Aedes control in liaison or integrated with malaria elimination programmes; vector competence, peridomestic behaviour and biology of African Ae. aegypti, especially the ecotypes, and of the other Aedes spp. 
previously incriminated or suspected as potential vectors; and occurrence and distribution of dengue, chikungunya and Zika virus infections in non-human primates and other potential 'reservoir' hosts.

Supplementary Materials: The following are available online at www.mdpi.com/xxx/s1, Supplementary Materials (Methods and References).

Acknowledgments: B.K. is supported by the Wellcome Trust (204862/Z/16/Z). C.L.M. and F.M.S. are supported by the Wellcome Trust (108440/Z/15/Z). L.L. receives support from the Agence Nationale de la Recherche (grants ANR-16-CE35-0004-01 and ANR-17-ERC2-0016-01), the French Government's Investissement d'Avenir program Laboratoire d'Excellence Integrative Biology of Emerging Infectious Diseases (grant ANR-10-LABX-62-IBEID), the City of Paris Emergence(s) program in Biomedical Research, the European Union's Horizon 2020 research and innovation programme under ZikaPLAN grant agreement No. 734584, and the Ecology of Health program of Centre National de la Recherche Scientifique (grant AFRICAEDES). A.B. is supported by a WHO/TDR grant (RCS-KM 2015 ID235974). P.J.M. receives personal support from The Medical Research Council (Grant No. MR/M011941/1), Wellcome Trust (200222/Z/15/Z MiRA) and the Bill and Melinda Gates Foundation (OPP1159078). We thank Maria Devine for her help sourcing new publications that have reported these Aedes species in Africa. D.W., C.L.M., J.P. and M.C. would like to thank members of the WIN network for fruitful discussions on Aedes insecticide resistance.

Author Contributions: D.W., B.K., A.B., C.L.M., F.M.S., M.C., J.P., L.L. and P.J.M. contributed text for the article based on their individual skills and experience, and all authors reviewed, discussed, and agreed on the final draft of the manuscript.

Conflicts of Interest: The authors declare they have no conflicts of interest.

\section{References}

1. Dick, G.W.; Kitchen, S.F.; Haddow, A.J. Zika virus. I. Isolations and serological specificity. Trans. R. Soc. Trop. Med. Hyg. 1952, 46, 509-520. [CrossRef]

2. Bhatt, S.; Gething, P.W.; Brady, O.J.; Messina, J.P.; Farlow, A.W.; Moyes, C.L.; Drake, J.M.; Brownstein, J.S.; Hoen, A.G.; Sankoh, O.; et al. The global distribution and burden of dengue. Nature 2013, 496, 504-507. [CrossRef] [PubMed]

3. Jaenisch, T.; Junghans, T.; Wills, B.; Brady, O.J.; Eckerle, I.; Farlow, A.; Hay, S.I.; McCall, P.J.; Messina, J.P.; Ofula, V.; et al. Dengue expansion in Africa-not recognized or not happening? Emerg. Infect. Dis. 2014, 20. [CrossRef] [PubMed]

4. Chan, M. Yellow fever: The resurgence of a forgotten disease. Lancet 2016, 387, 2165-2166. [CrossRef]

5. Garske, T.; Van Kerkhove, M.D.; Yactayo, S.; Ronveaux, O.; Lewis, R.F.; Staples, J.E.; Perea, W.; Ferguson, N.M. Yellow fever in Africa: Estimating the burden of disease and impact of mass vaccination from outbreak and serological data. PLoS Med. 2014, 11, e1001638. [CrossRef] [PubMed]

6. Jentes, E.S.; Poumerol, G.; Gershman, M.D.; Hill, D.R.; Lemarchand, J.; Lewis, R.F.; Staples, J.E.; Tomori, O.; Wilder-Smith, A.; Monath, T.P. The revised global yellow fever risk map and recommendations for vaccination, 2010: Consensus of the informal WHO working group on geographic risk for yellow fever. Lancet Infect. Dis. 2011, 11, 622-632. [CrossRef]

7. Stoler, J.; Al Dashti, R.; Anto, F.; Fobil, J.N.; Awandare, G.A. Deconstructing "malaria": West Africa as the next front for dengue fever surveillance and control. Acta Trop. 2014, 134, 58-65. [CrossRef] [PubMed]

8. Kindhauser, M.K.; Allen, T.; Frank, V.; Santhana, R.S.; Dye, C. Zika: The origin and spread of a mosquito-borne virus. Bull. World Health Organ. 2016, 94, 675C-686C. [CrossRef] [PubMed]

9. Burt, F.J.; Chen, W.; Miner, J.J.; Lenschow, D.J.; Merits, A.; Schnettler, E.; Kohl, A.; Rudd, P.A.; Taylor, A.; Herrero, L.J.; et al. Chikungunya virus: An update on the biology and pathogenesis of this emerging pathogen. Lancet Infect. Dis. 2017, 17, e107-e117. [CrossRef]

10. Barrett, A.D.; Higgs, S. Yellow fever: A disease that has yet to be conquered. Ann. Rev. Entomol. 2007, 52, 209-229. [CrossRef] [PubMed]

11. Holmes, E.C.; Twiddy, S.S. The origin, emergence and evolutionary genetics of dengue virus. Infect. Genet Evol. 2003, 3, 19-28. [CrossRef]

12. Mattingly, P.F. Genetical aspects of the Aedes aegypti problem: I. Taxonomy and bionomics. Ann. Trop. Med. Parasitol. 1957, 51, 392-408. [CrossRef] [PubMed]

13. Moore, M.; Sylla, M.; Goss, L.; Burugu, M.W.; Sang, R.; Kamau, L.W.; Kenya, E.U.; Bosio, C.; Munoz Mde, L.; Sharakova, M.; et al. Dual African origins of global Aedes aegypti s.l. populations revealed by mitochondrial DNA. PLoS Negl. Trop. Dis. 2013, 7, e2175. [CrossRef] [PubMed] 
14. Tabachnick, W.J. Evolutionary genetics and arthropod-borne disease: The yellow fever mosquito. Am. Entomol. 1991, 37, 14-26. [CrossRef]

15. World Health Organization. Yellow fever: Rapid field entomological assessment during yellow fever outbreaks in Africa. In Methodological Field Approaches for Scientists with a Basic Background in Entomology; World Health Organization: Geneva, Switzerland, 2014.

16. Tsetsarkin, K.A.; Vanlandingham, D.L.; McGee, C.E.; Higgs, S. A single mutation in chikungunya virus affects vector specificity and epidemic potential. PLoS Pathog. 2007, 3, e201. [CrossRef] [PubMed]

17. Yuan, L.; Huang, X.Y.; Liu, Z.Y.; Zhang, F.; Zhu, X.L.; Yu, J.Y.; Ji, X.; Xu, Y.P.; Li, G.; Li, C.; et al. A single mutation in the PRM protein of Zika virus contributes to fetal microcephaly. Science 2017, 358, 933-936. [CrossRef] [PubMed]

18. Magalhaes, T.; Foy, B.D.; Marques, E.T.A.; Ebel, G.D.; Weger-Lucarelli, J. Mosquito-borne and sexual transmission of Zika virus: Recent developments and future directions. Virus Res. 2017. [CrossRef] [PubMed]

19. Moyes, C.L.; Vontas, J.; Martins, A.J.; Ng, L.C.; Koou, S.Y.; Dusfour, I.; Raghavendra, K.; Pinto, J.; Corbel, V.; David, J.P.; et al. Contemporary status of insecticide resistance in the major Aedes vectors of arboviruses infecting humans. PLoS Negl. Trop. Dis. 2017, 11, e0005625. [CrossRef] [PubMed]

20. Alirol, E.; Getaz, L.; Stoll, B.; Chappuis, F.; Loutan, L. Urbanisation and infectious diseases in a globalised world. Lancet Infect. Dis. 2011, 11, 131-141. [CrossRef]

21. World Bank, Geneva. Gross Domestic Product 2016. Available online: databank.worldbank.org/data/ download/GDP.pdf (accessed on 26 January 2018).

22. Weaver, S.C. Emergence of epidemic Zika virus transmission and congenital Zika syndrome: Are recently evolved traits to blame? mBio 2017, 8, e02063-16. [CrossRef] [PubMed]

23. Wetsman, N. The missing pieces: Lack of Zika data from Africa complicates search for answers. Nat. Med. 2017, 23, 904-906. [CrossRef] [PubMed]

24. Messina, J.P.; Kraemer, M.U.; Brady, O.J.; Pigott, D.M.; Shearer, F.M.; Weiss, D.J.; Golding, N.; Ruktanonchai, C.W.; Gething, P.W.; Cohn, E.; et al. Mapping global environmental suitability for Zika virus. eLife 2016, 5, e15272. [CrossRef] [PubMed]

25. Nsoesie, E.O.; Kraemer, M.U.; Golding, N.; Pigott, D.M.; Brady, O.J.; Moyes, C.L.; Johansson, M.A.; Gething, P.W.; Velayudhan, R.; Khan, K.; et al. Global distribution and environmental suitability for chikungunya virus, 1952 to 2015. Eurosurveill. Eur. Commun. Dis. Bull. 2016, 21. [CrossRef] [PubMed]

26. Shearer, F.; Longbottom, J.; Browne, A.; Pigott, D.M.; Brady, O.J.; Kraemer, M.U.G.; Marinho, F.; Yactayo, S.; Valdelaine, E.M.; Aglaer, A.; et al. Existing and potential infection risk zones of yellow fever worldwide: A modelling analysis. Lancet Glob. Health 2018. [CrossRef]

27. Messina, J.P.; Brady, O.J.; Pigott, D.M.; Brownstein, J.S.; Hoen, A.G.; Hay, S.I. A global compendium of human dengue virus occurrence. Sci. Data 2014, 1, 140004. [CrossRef] [PubMed]

28. Patching, H.M.; Hudson, L.M.; Cooke, W.; Garcia, A.J.; Hay, S.I.; Roberts, M.; Moyes, C.L. A supervised learning process to validate online disease reports for use in predictive models. Big Data 2015, 3, $230-237$. [CrossRef] [PubMed]

29. Shearer, F.M.; Moyes, C.L.; Pigott, D.M.; Brady, O.J.; Marinho, F.; Deshpande, A.; Longbottom, J.; Browne, A.J.; Kraemer, M.U.G.; O'Reilly, K.M.; et al. Global yellow fever vaccination coverage from 1970 to 2016: An adjusted retrospective analysis. Lancet Infect. Dis. 2017, 17, 1209-1217. [CrossRef]

30. Gabor, J.J.; Schwarz, N.G.; Esen, M.; Kremsner, P.G.; Grobusch, M.P. Dengue and chikungunya seroprevalence in Gabonese infants prior to major outbreaks in 2007 and 2010: A sero-epidemiological study. Travel Med. Infect. Dis. 2016, 14, 26-31. [CrossRef] [PubMed]

31. Ochieng, C.; Ahenda, P.; Vittor, A.Y.; Nyoka, R.; Gikunju, S.; Wachira, C.; Waiboci, L.; Umuro, M.; Kim, A.A.; Nderitu, L. Seroprevalence of infections with dengue, rift valley fever and chikungunya viruses in Kenya, 2007. PLoS ONE 2015, 10, e0132645. [CrossRef] [PubMed]

32. Gake, B.; Vernet, M.A.; Leparc-Goffart, I.; Drexler, J.; Gould, E.A.; Gallian, P.; Lamballerie, X. Low seroprevalence of Zika virus in Cameroonian blood donors. Braz. J. Infect. Dis. 2017, 21, 481-483. [CrossRef] [PubMed]

33. Solomon, T.; Mallewa, M. Dengue and other emerging flaviviruses. J. Infect. 2001, 42, 104-115. [CrossRef] [PubMed] 
34. Kraemer, M.U.; Sinka, M.E.; Duda, K.A.; Mylne, A.Q.; Shearer, F.M.; Barker, C.M.; Moore, C.G.; Carvalho, R.G.; Coelho, G.E.; Van Bortel, W.; et al. The global distribution of the arbovirus vectors Aedes aegypti and Ae. albopictus. eLife 2015, 4, e08347. [CrossRef] [PubMed]

35. Kraemer, M.U.; Sinka, M.E.; Duda, K.A.; Mylne, A.; Shearer, F.M.; Brady, O.J.; Messina, J.P.; Barker, C.M.; Moore, C.G.; Carvalho, R.G.; et al. The global compendium of Aedes aegypti and Ae. albopictus occurrence. Sci. Data 2015, 2. [CrossRef] [PubMed]

36. Agwu, E.J.; Igbinosa, I.B.; Isaac, C. Entomological assessment of yellow fever-epidemic risk indices in Benue State, Nigeria, 2010-2011. Acta Trop. 2016, 161, 18-25. [CrossRef] [PubMed]

37. Ayorinde, A.; Oboh, B.; Oduola, A.; Otubanjo, O. The insecticide susceptibility status of Aedes aegypti (Diptera: Culicidae) in farm and nonfarm sites of Lagos State, Nigeria. J. Insect Sci. 2015, 15. [CrossRef] [PubMed]

38. Benallal, K.E.; Allal-Ikhlef, A.; Benhamouda, K.; Schaffner, F.; Harrat, Z. First report of Aedes (Stegomyia) albopictus (Diptera: Culicidae) in Oran, West of Algeria. Acta Trop. 2016, 164, 411-413. [CrossRef] [PubMed]

39. Bennouna, A.; Balenghien, T.; El Rhaffouli, H.; Schaffner, F.; Garros, C.; Gardes, L.; Lhor, Y.; Hammoumi, S.; Chlyeh, G.; Fassi, F.O. First record of Stegomyia albopicta (=Aedes albopictus) in Morocco: A major threat to public health in North Africa? Med. Vet. Entomol. 2017, 31, 102-106. [CrossRef] [PubMed]

40. Centers for Disease Control and Prevention. Ongoing dengue epidemic-Angola. Morb. Mortal. Wkly. Rep. 2013, 62, 504-507.

41. Chepkorir, E.; Lutomiah, J.; Mutisya, J.; Mulwa, F.; Limbaso, K.; Orindi, B.; Sang, R. Vector competence of Aedes aegypti populations from Kilifi and Nairobi for dengue 2 virus and the influence of temperature. Parasites Vectors 2014, 7, 435. [CrossRef] [PubMed]

42. Da Moura, A.J.F.; Santos, M.A.V.d.; Oliveira, C.M.F.; Guedes, D.R.D.; de Carvalho-Leandro, D.; Brito, M.L.d.; Rocha, H.D.R.; Gómez, L.F.; Ayres, C.F.J. Vector competence of the Aedes aegypti population from Santiago Island, Cape Verde, to different serotypes of dengue virus. Parasites Vectors 2015, 8, 114. [CrossRef] [PubMed]

43. Dia, I.; Diagne, C.T.; Ba, Y.; Diallo, D.; Konate, L.; Diallo, M. Insecticide susceptibility of Aedes aegypti populations from Senegal and Cape Verde Archipelago. Parasites Vectors 2012, 5, 238. [CrossRef] [PubMed]

44. Donpedro, K.N.; Adegbite, T.O. Nuvan resistance in a field strain of Aedes aegypti (L.) in Lagos, Nigeria. Environ. Pollut. Ser. A Ecol. Biol. 1985, 38, 19-29. [CrossRef]

45. Gaye, A.; Faye, O.; Diagne, C.T.; Faye, O.; Diallo, D.; Weaver, S.C.; Sall, A.A.; Diallo, M. Oral susceptibility of Aedes aegypti (Diptera: Culicidae) from Senegal for dengue serotypes 1 and 3 viruses. Trop. Med. Int. Health 2014, 19, 1355-1359. [CrossRef] [PubMed]

46. Guindo-Coulibaly, N.; Adja, A.M.; Koffi, A.A.; Diakité, N.R.; Ahoua Alou, P.L.; Bassa, K.F.; N'Goran, K.E. Insecticides susceptibility of two distinct morphologies at larval stage of Aedes aegypti (Diptera: Culicidae) from Abidjan (Côte d'Ivoire). Eur. J. Sci. Res. 2014, 126, 434-443.

47. Hertz, J.T.; Lyaruu, L.J.; Ooi, E.E.; Mosha, F.W.; Crump, J.A. Distribution of Aedes mosquitoes in the Kilimanjaro region of northern Tanzania. Pathog. Glob. Health 2016, 110, 108-112. [CrossRef] [PubMed]

48. Husham, A.O.; Abdalmagid, M.A.; Brair, M. Status susceptibility of dengue vector; Aedes aegypti to different groups of insecticides in Port Sudan City-Red Sea. Sudan. J. Public Health 2010, 10, 199-202.

49. Kamgang, B.; Marcombe, S.; Chandre, F.; Nchoutpouen, E.; Nwane, P.; Etang, J.; Corbel, V.; Paupy, C. Insecticide susceptibility of Aedes aegypti and Aedes albopictus in Central Africa. Parasites Vectors 2010, 4, 79. [CrossRef] [PubMed]

50. Kampango, A.; Abilio, A.P. The Asian tiger hunts in Maputo city-the first confirmed report of Aedes (Stegomyia) albopictus (Skuse, 1895) in Mozambique. Parasites Vectors 2016, 9, 76. [CrossRef] [PubMed]

51. Kawada, H.; Higa, Y.; Futami, K.; Muranami, Y.; Kawashima, E.; Osei, J.H.; Sakyi, K.Y.; Dadzie, S.; de Souza, D.K.; Appawu, M.; et al. Discovery of point mutations in the voltage-gated sodium channel from African Aedes aegypti populations: Potential phylogenetic reasons for gene introgression. PLoS Negl. Trop. Dis. 2016, 10, e0004780. [CrossRef] [PubMed]

52. Konan, L.Y.; Coulibaly, I.Z.; Kone, B.A.; Ziogba, J.T.; Diallo, A.; Ekra, D.K.; Traoré, K.S.; Doannio, M.C.J.; Paul, O. Aedes aegypti susceptibility to insecticide from Abidjan City, Cote d'ivoire. Vector Borne Zoonotic Dis. 2012, 12, 325-329. [CrossRef] [PubMed]

53. Konan, Y.L.; Coulibaly, Z.I.; Allali, K.B.; Tetchi, S.M.; Kone, A.B.; Coulibaly, D.; Ekra, K.D.; Doannio, J.M.; Oudéhouri-Koudou, P. Management of the yellow fever epidemic in 2010 in Seguela (Cote d'Ivoire): Value of multidisciplinary investigation. Sante Publique 2014, 26, 859-867. [CrossRef] [PubMed] 
54. Lutomiah, J.; Barrera, R.; Makio, A.; Mutisya, J.; Koka, H.; Owaka, S.; Koskei, E.; Nyunja, A.; Eyase, F.; Coldren, R.; et al. Dengue outbreak in Mombasa City, Kenya, 2013-2014: Entomologic investigations. PLoS Negl. Trop. Dis. 2016, 10, e0004981. [CrossRef] [PubMed]

55. Massangaie, M.; Pinto, G.; Padama, F.; Chambe, G.; da Silva, M.; Mate, I.; Chirindza, C.; Ali, S.; Agostinho, S.; Chilaule, D.; et al. Clinical and epidemiological characterization of the first recognized outbreak of dengue virus-type 2 in Mozambique, 2014. Am. J. Trop. Med. Hyg. 2016, 94, 413-416. [CrossRef] [PubMed]

56. Mouchet, J. La resistance aux insecticides chez Aedes aegypti et les especes voisines. Bull. World Health Organ. 1967, 36, 569-577. [PubMed]

57. Müller, G.C.; Tsabari, O.; Traore, M.M.; Traore, S.F.; Kravchenko, V.D.; Junnila, A.; Beier, J.C. First record of Aedes albopictus in inland Africa along the River Niger in Bamako and Mopti, Mali. Acta Trop. 2016, 162, 245-247. [CrossRef] [PubMed]

58. Ngoagouni, C.; Kamgang, B.; Brengues, C.; Yahouedo, G.; Paupy, C.; Nakouné, E.; Kazanji, M.; Chandre, F. Susceptibility profile and metabolic mechanisms involved in Aedes aegypti and Aedes albopictus resistant to DDT and deltamethrin in the Central African Republic. Parasites Vectors 2016, 9, 599. [CrossRef] [PubMed]

59. Noden, B.H.; Musuuo, M.; Aku-Akai, L.; van der Colf, B.; Chipare, I.; Wilkinson, R. Risk assessment of flavivirus transmission in Namibia. Acta Trop. 2014, 137, 123-129. [CrossRef] [PubMed]

60. Oduola, A.O.; Obembe, A.; Adelaja, O.J.; Ande, A.T. Surveillance and insecticide susceptibility status of culicine mosquitoes in selected communities utilizing long-lasting insecticidal nets in Kwara State, Nigeria. Anim. Res. Int. 2016, 13, 2483-2491.

61. Pocquet, N.; Darriet, F.; Zumbo, B.; Milesi, P.; Thiria, J.; Bernard, V.; Toty, C.; Labbé, P.; Chandre, F. Insecticide resistance in disease vectors from Mayotte: An opportunity for integrated vector management. Parasites Vectors 2014, 7, 299. [CrossRef] [PubMed]

62. Reis, S.; Cornel, A.J.; Melo, M.; Pereira, H.; Loiseau, C. First record of Aedes albopictus (Skuse 1894) on Sâo Tomé island. Acta Trop. 2017, 171, 86-89. [CrossRef] [PubMed]

63. Ribeiro Rocha, H.D.; Santos Paiva, M.H.; Machado Silva, N.; Araújo, A.P.; de Azevedo Camacho, D.d.R.d.; da Moura, A.J.F.; Ferrero Gómez, L.; Junqueira Ayres, C.F.; de Melo Santos, M.A.V. Susceptibility profile of Aedes aegypti from Santiago Island, Cabo Verde, to insecticides. Acta Trop. 2015, 152, 66-73. [CrossRef] [PubMed]

64. Self, L.S.; Pant, C.P. Insecticide susceptibility and resistance in populations of Anopheles gambiae, Culex fatigans and Aedes aegypti in southern Nigeria. Bull. World Health Organ. 1966, 24, 960-962.

65. Lindsay, S.W.; Wilson, A.; Golding, N.; Scott, T.W.; Takken, W. Improving the built environment in urban areas to control Aedes aegypti-borne diseases. Bull. World Health Organ. 2017, 95, 607-608. [CrossRef] [PubMed]

66. Talla, C.; Diallo, D.; Dia, I.; Ba, Y.; Ndione, J.; Morse, A.P.; Diop, A.; Diallo, M. Modelling hotspots of the two dominant Rift Valley fever vectors (Aedes vexans and Culex poicilipes) in Barkedji, Senegal. Parasites Vectors 2016, 9, 111. [CrossRef] [PubMed]

67. Brady, O.J.; Johansson, M.A.; Guerra, C.A.; Bhatt, S.; Golding, N.; Pigott, D.M.; Delatte, H.; Grech, M.G.; Leisnham, P.T.; Maciel-de-Freitas, R.; et al. Modelling adult Aedes aegypti and Aedes albopictus survival at different temperatures in laboratory and field settings. Parasites Vectors 2013, 6, 351. [CrossRef] [PubMed]

68. Sang, R.; Lutomiah, J.; Said, M.; Makio, A.; Koka, H.; Koskei, E.; Nyunja, A.; Owaka, S.; Matoke-Muhia, D.; Bukachi, S.; et al. Effects of irrigation and rainfall on the population dynamics of rift valley fever and other arbovirus mosquito vectors in the epidemic-prone Tana River County, Kenya. J. Med. Entomol. 2017, 54, 460-470. [CrossRef] [PubMed]

69. Kamgang, B.; Happi, J.Y.; Boisier, P.; Njiokou, F.; Hervé, J.P.; Simard, F.; Paupy, C. Geographic and ecological distribution of the dengue and chikungunya virus vectors Aedes aegypti and Aedes albopictus in three major Cameroonian towns. Med. Vet. Entomol. 2010, 24, 132-141. [CrossRef] [PubMed]

70. Kamgang, B.; Ngoagouni, C.; Manirakiza, A.; Nakouné, E.; Paupy, C.; Kazanji, M. Temporal patterns of abundance of Aedes aegypti and Aedes albopictus (Diptera: Culicidae) and mitochondrial DNA analysis of Ae. albopictus in the Central African Republic. PLoS Negl. Trop. Dis. 2013, 7, e2590. [CrossRef] [PubMed]

71. Kamgang, B.; Yougang, A.P.; Tchoupo, M.; Riveron, J.M.; Wondji, C. Temporal distribution and insecticide resistance profile of two major arbovirus vectors Aedes aegypti and Aedes albopictus in Yaoundé, the capital city of Cameroon. Parasites Vectors 2017, 10, 469. [CrossRef] [PubMed] 
72. Zahouli, J.B.Z.; Koudou, B.G.; Muller, P.; Malone, D.; Tano, Y.; Utzinger, J. Effect of land-use changes on the abundance, distribution, and host-seeking behavior of Aedes arbovirus vectors in oil palm-dominated landscapes, southeastern Cote d'Ivoire. PLoS ONE 2017, 12, e0189082. [CrossRef] [PubMed]

73. Lambrechts, L.; Scott, T.W.; Gubler, D.J. Consequences of the expanding global distribution of Aedes albopictus for dengue virus transmission. PLoS Negl. Trop. Dis. 2010, 4, e646. [CrossRef] [PubMed]

74. Weaver, S.C.; Forrester, N.L. Chikungunya: Evolutionary history and recent epidemic spread. Antivir. Res. 2015, 120, 32-39. [CrossRef] [PubMed]

75. Pages, F.; Peyrefitte, C.N.; Mve, M.T.; Jarjaval, F.; Brisse, S.; Iteman, I.; Gravier, P.; Nkoghe, D.; Grandadam, M. Aedes albopictus mosquito: The main vector of the 2007 chikungunya outbreak in Gabon. PLoS ONE 2009, 4, e4691. [CrossRef]

76. Paupy, C.; Ollomo, B.; Kamgang, B.; Moutailler, S.; Rousset, D.; Demanou, M.; Herve, J.P.; Leroy, E.; Simard, F. Comparative role of Aedes albopictus and Aedes aegypti in the emergence of dengue and chikungunya in Central Africa. Vector Borne Zoonotic Dis. 2010, 10, 259-266. [CrossRef] [PubMed]

77. Grard, G.; Caron, M.; Mombo, I.M.; Nkoghe, D.; Mboui Ondo, S.; Jiolle, D.; Fontenille, D.; Paupy, C.; Leroy, E.M. Zika virus in Gabon (Central Africa)-2007: A new threat from Aedes albopictus? PLoS Negl. Trop. Dis. 2014, 8, e2681. [CrossRef] [PubMed]

78. Paupy, C.; Kassa Kassa, F.; Caron, M.; Nkoghe, D.; Leroy, E.M. A chikungunya outbreak associated with the vector Aedes albopictus in remote villages of Gabon. Vector Borne Zoonotic Dis. 2012, 12, 167-169. [CrossRef] [PubMed]

79. Ngoagouni, C.; Kamgang, B.; Nakoune, E.; Paupy, C.; Kazanji, M. Invasion of Aedes albopictus (Diptera: Culicidae) into Central Africa: What consequences for emerging diseases? Parasites Vectors 2015, 8, 191. [CrossRef] [PubMed]

80. Powell, J.R.; Tabachnick, W.J. History of domestication and spread of Aedes aegypti-A review. Mem. Inst. Oswaldo Cruz 2013, 108 (Suppl. 1), 11-17. [CrossRef] [PubMed]

81. Brown, J.E.; McBride, C.S.; Johnson, P.; Ritchie, S.; Paupy, C.; Bossin, H.; Lutomiah, J.; Fernandez-Salas, I.; Ponlawat, A.; Cornel, A.J.; et al. Worldwide patterns of genetic differentiation imply multiple 'domestications' of Aedes aegypti, a major vector of human diseases. Proc. Biol. Sci. 2011, 278, 2446-2454. [CrossRef] [PubMed]

82. Crawford, J.E.; Alves, J.M.; Palmer, W.J.; Day, J.P.; Sylla, M.; Ramasamy, R.; Surendran, S.N.; Black, W.C.T.; Pain, A.; Jiggins, F.M. Population genomics reveals that an anthropophilic population of Aedes aegypti mosquitoes in West Africa recently gave rise to American and Asian populations of this major disease vector. BMC Biol. 2017, 15, 16. [CrossRef] [PubMed]

83. Dickson, L.B.; Jiolle, D.; Minard, G.; Moltini-Conclois, I.; Volant, S.; Ghozlane, A.; Bouchier, C.; Ayala, D.; Paupy, C.; Moro, C.V.; et al. Carryover effects of larval exposure to different environmental bacteria drive adult trait variation in a mosquito vector. Sci. Adv. 2017, 3, e1700585. [CrossRef] [PubMed]

84. Powell, J.R. Mosquitoes on the move. Science 2016, 354, 971-972. [CrossRef] [PubMed]

85. Mattingly, P.F. Taxonomy of Aedes aegypti and related species. Bull. World Health Organ. 1967, 36, 552-554. [PubMed]

86. McClelland, G.A.H. A worldwide survey of variation in scale pattern of the abdominal tergum of Aedes aegypti (L.) (Diptera: Culicidae). Trans. R. Entomol. Soc. Lond. 1974, 126, 239-259. [CrossRef]

87. Huber, K.; Ba, Y.; Dia, I.; Mathiot, C.; Sall, A.A.; Diallo, M. Aedes aegypti in Senegal: Genetic diversity and genetic structure of domestic and sylvatic populations. Am. J. Trop. Med. Hyg. 2008, 79, 218-229. [PubMed]

88. Paupy, C.; Brengues, C.; Ndiath, O.; Toty, C.; Herve, J.P.; Simard, F. Morphological and genetic variability within Aedes aegypti in Niakhar, Senegal. Infect. Genet. Evol. 2010, 10, 473-480. [CrossRef] [PubMed]

89. Sylla, M.; Bosio, C.; Urdaneta-Marquez, L.; Ndiaye, M.; Black, W.C.T. Gene flow, subspecies composition, and dengue virus-2 susceptibility among Aedes aegypti collections in Senegal. PLoS Negl. Trop. Dis. 2009, 3, e408. [CrossRef] [PubMed]

90. Gloria-Soria, A.; Ayala, D.; Bheecarry, A.; Calderon-Arguedas, O.; Chadee, D.D.; Chiappero, M.; Coetzee, M.; Elahee, K.B.; Fernandez-Salas, I.; Kamal, H.A.; et al. Global genetic diversity of Aedes aegypti. Mol. Ecol. 2016, 25, 5377-5395. [CrossRef] [PubMed]

91. Brown, J.E.; Evans, B.R.; Zheng, W.; Obas, V.; Barrera-Martinez, L.; Egizi, A.; Zhao, H.; Caccone, A.; Powell, J.R. Human impacts have shaped historical and recent evolution in Aedes aegypti, the dengue and yellow fever mosquito. Evol. Int. J. Org. Evol. 2014, 68, 514-525. [CrossRef] [PubMed] 
92. Black, W.C.; Bennett, K.E.; Gorrochotegui-Escalante, N.; Barillas-Mury, C.V.; Fernandez-Salas, I.; de Lourdes Munoz, M.; Farfan-Ale, J.A.; Olson, K.E.; Beaty, B.J. Flavivirus susceptibility in Aedes aegypti. Arch. Med. Res. 2002, 33, 379-388. [CrossRef]

93. Bosio, C.F.; Beaty, B.J.; Black, W.C. Quantitative genetics of vector competence for dengue-2 virus in Aedes aegypti. Am. J. Trop. Med. Hyg. 1998, 59, 965-970. [CrossRef] [PubMed]

94. Tabachnick, W.J.; Wallis, G.P.; Aitken, T.H.; Miller, B.R.; Amato, G.D.; Lorenz, L.; Powell, J.R.; Beaty, B.J. Oral infection of Aedes aegypti with yellow fever virus: Geographic variation and genetic considerations. Am. J. Trop. Med. Hyg. 1985, 34, 1219-1224. [CrossRef] [PubMed]

95. Diallo, M.; Ba, Y.; Faye, O.; Soumare, M.L.; Dia, I.; Sall, A.A. Vector competence of Aedes aegypti populations from Senegal for sylvatic and epidemic dengue 2 virus isolated in West Africa. Trans. R. Soc. Trop. Med. Hyg. 2008, 102, 493-498. [CrossRef] [PubMed]

96. Diallo, M.; Sall, A.A.; Moncayo, A.C.; Ba, Y.; Fernandez, Z.; Ortiz, D.; Coffey, L.L.; Mathiot, C.; Tesh, R.B.; Weaver, S.C. Potential role of sylvatic and domestic African mosquito species in dengue emergence. Am. J. Trop. Med. Hyg. 2005, 73, 445-449. [PubMed]

97. Dickson, L.B.; Sanchez-Vargas, I.; Sylla, M.; Fleming, K.; Black, W.C. Vector competence in West African Aedes aegypti is flavivirus species and genotype dependent. PLoS Negl. Trop. Dis. 2014, 8, e3153. [CrossRef] [PubMed]

98. Vazeille, M.; Yebakima, A.; Lourenco-de-Oliveira, R.; Andriamahefazafy, B.; Correira, A.; Rodrigues, J.M.; Veiga, A.; Moreira, A.; Leparc-Goffart, I.; Grandadam, M.; et al. Oral receptivity of Aedes aegypti from Cape Verde for yellow fever, dengue, and chikungunya viruses. Vector Borne Zoonotic Dis. 2013, 13, 37-40. [CrossRef] [PubMed]

99. Lambrechts, L. Dissecting the genetic architecture of host-pathogen specificity. PLoS Pathog. 2010, 6, e1001019. [CrossRef] [PubMed]

100. Haddow, A.J.; Smithburn, K.C.; Dick, G.W.A.; Kitchen, S.F.; Lumsden, W.H.R. Implication of the mosquito Aedes (Stegomyia) africanus Theobald in the forest cycle of yellow fever in Uganda. Ann. Trop. Med. Parasitol. 1948, 42, 218-223. [CrossRef] [PubMed]

101. Hanley, K.A.; Monath, T.P.; Weaver, S.C.; Rossi, S.L.; Richman, R.L.; Vasilakis, N. Fever versus fever: The role of host and vector susceptibility and interspecific competition in shaping the current and future distributions of the sylvatic cycles of dengue virus and yellow fever virus. Infect. Genet. Evol. 2013, 19, 292-311. [CrossRef] [PubMed]

102. Haddow, A.J. Mosquito-borne viruses-The need for a balanced team. In Medical Entomology Centenary; Royal Society of Tropical Medicine and Hygiene: London, UK, 1977; pp. 33-38.

103. Weaver, S.C.; Reisen, W.K. Present and future arboviral threats. Antivir. Res. 2010, 85, 328-345. [CrossRef] [PubMed]

104. Diallo, D.; Chen, R.; Diagne, C.T.; Ba, Y.; Dia, I.; Sall, A.A.; Weaver, S.C.; Diallo, M. Bloodfeeding patterns of sylvatic arbovirus vectors in southeastern Senegal. Trans. R. Soc. Trop. Med. Hyg. 2013, 107, 200-203. [CrossRef] [PubMed]

105. Haddow, A.J.; Williams, M.C.; Woodall, J.P.; Simpson, D.I.; Goma, L.K. Twelve isolations of Zika virus from Aedes (Stegomyia) africanus (Theobald) taken in and above a Uganda forest. Bull. World Health Organ. 1964, 31, 57-69. [PubMed]

106. Ngoagouni, C.; Kamgang, B.; Manirakiza, A.; Nangouma, A.; Paupy, C.; Nakoune, E.; Kazanji, M. Entomological profile of yellow fever epidemics in the Central African Republic, 2006-2010. Parasites Vectors 2012, 5, 175. [CrossRef] [PubMed]

107. Diallo, D.; Sall, A.A.; Buenemann, M.; Chen, R.; Faye, O.; Diagne, C.T.; Faye, O.; Ba, Y.; Dia, I.; Watts, D.; et al. Landscape ecology of sylvatic chikungunya virus and mosquito vectors in southeastern Senegal. PLoS Negl. Trop. Dis. 2012, 6, e1649. [CrossRef] [PubMed]

108. Diallo, M.; Ba, Y.; Sall, A.A.; Diop, O.M.; Ndione, J.A.; Mondo, M.; Girault, L.; Mathiot, C. Amplification of the sylvatic cycle of dengue virus type 2, Senegal, 1999-2000: Entomologic findings and epidemiologic considerations. Emerg. Infect. Dis. 2003, 9, 362-367. [CrossRef] [PubMed]

109. Kuno, G.; Mackenzie, J.S.; Junglen, S.; Hubalek, Z.; Plyusnin, A.; Gubler, D.J. Vertebrate reservoirs of arboviruses: Myth, synonym of amplifier, or reality? Viruses 2017, 9, 185. [CrossRef] [PubMed] 
110. Diagne, C.T.; Diallo, D.; Faye, O.; Ba, Y.; Faye, O.; Gaye, A.; Dia, I.; Faye, O.; Weaver, S.C.; Sall, A.A.; et al. Potential of selected Senegalese Aedes spp. mosquitoes (Diptera: Culicidae) to transmit Zika virus. BMC Infect. Dis. 2015, 15, 492. [CrossRef] [PubMed]

111. Diallo, D.; Sall, A.A.; Diagne, C.T.; Faye, O.; Faye, O.; Ba, Y.; Hanley, K.A.; Buenemann, M.; Weaver, S.C.; Diallo, M. Zika virus emergence in mosquitoes in southeastern Senegal, 2011. PLoS ONE 2014, 9, e109442. [CrossRef] [PubMed]

112. Epelboin, Y.; Talaga, S.; Epelboin, L.; Dusfour, I. Zika virus: An updated review of competent or naturally infected mosquitoes. PLoS Negl. Trop. Dis. 2017, 11, e0005933. [CrossRef] [PubMed]

113. Althouse, B.M.; Vasilakis, N.; Sall, A.A.; Diallo, M.; Weaver, S.C.; Hanley, K.A. Potential for Zika virus to establish a sylvatic transmission cycle in the Americas. PLoS Negl. Trop. Dis. 2016, 10, e0005055. [CrossRef] [PubMed]

114. Lambrechts, L.; Chevillon, C.; Albright, R.G.; Thaisomboonsuk, B.; Richardson, J.H.; Jarman, R.G.; Scott, T.W. Genetic specificity and potential for local adaptation between dengue viruses and mosquito vectors. BMC Evol. Biol. 2009, 9, 160. [CrossRef] [PubMed]

115. Eastwood, G.; Sang, R.C.; Guerbois, M.; Taracha, E.L.N.; Weaver, S.C. Enzootic circulation of chikungunya virus in East Africa: Serological evidence in non-human Kenyan primates. Am. J. Trop. Med. Hyg. 2017, 97, 1399-1404. [CrossRef] [PubMed]

116. Achee, N.L.; Gould, F.; Perkins, T.A.; Reiner, R.C., Jr.; Morrison, A.C.; Ritchie, S.A.; Gubler, D.J.; Teyssou, R.; Scott, T.W. A critical assessment of vector control for dengue prevention. PLoS Negl. Trop. Dis. 2015, 9, e0003655. [CrossRef] [PubMed]

117. Bowman, L.R.; Donegan, S.; McCall, P.J. Is dengue vector control deficient in effectiveness or evidence? Systematic review and meta-analysis. PLoS Negl. Trop. Dis. 2016, 10, e0004551. [CrossRef] [PubMed]

118. Mahaffy, A.F. The yellow fever situation in Africa. Bull. World Health Organ. 1954, 11, 319-324. [PubMed]

119. Gubler, D.J. Dengue, urbanization and globalization: The unholy trinity of the 21st century. Trop. Med. Health 2011, 39, 3-11. [CrossRef] [PubMed]

120. Barrett, A.D. Yellow fever in Angola and beyond-the problem of vaccine supply and demand. N. Engl. J. Med. 2016, 375, 301-303. [CrossRef] [PubMed]

121. Godoi, I.P.; Lemos, L.L.; de Araujo, V.E.; Bonoto, B.C.; Godman, B.; Guerra Junior, A.A. CYD-TDV dengue vaccine: Systematic review and meta-analysis of efficacy, immunogenicity and safety. J. Comp. Eff. Res. 2017, 6, 165-180. [CrossRef] [PubMed]

122. Runge-Ranzinger, S.; McCall, P.J.; Kroeger, A.; Horstick, O. Dengue disease surveillance: An updated systematic literature review. Trop. Med. Int. Health 2014, 19, 1116-1160. [CrossRef] [PubMed]

123. Demanou, M.; Pouillot, R.; Grandadam, M.; Boisier, P.; Kamgang, B.; Herve, J.P.; Rogier, C.; Rousset, D.; Paupy, C. Evidence of dengue virus transmission and factors associated with the presence of anti-dengue virus antibodies in humans in three major towns in Cameroon. PLoS Negl. Trop. Dis. 2014, 8, e2950. [CrossRef] [PubMed]

124. Johnson, B.K.; Musoke, S.; Ocheng, D.; Gichogo, A.; Rees, P.H. Dengue-2 virus in Kenya. Lancet 1982, 2, 208-209. [CrossRef]

125. Vu, D.M.; Mutai, N.; Heath, C.J.; Vulule, J.M.; Mutuku, F.M.; Ndenga, B.A.; LaBeaud, A.D. Unrecognized dengue virus infections in children, western Kenya, 2014-2015. Emerg. Infect. Dis. 2017, 23, 1915-1917. [CrossRef] [PubMed]

126. Ward, T.; Samuel, M.; Maoz, D.; Runge-Ranzinger, S.; Boyce, R.; Toledo, J.; Velayudhan, R.; Horstick, O. Dengue data and surveillance in Tanzania: A systematic literature review. Trop. Med. Int. Health 2017, 22, 960-970. [CrossRef] [PubMed]

127. World Health Organization. Global Strategy for Dengue Prevention and Control, 2012-2020; World Health Organization: Geneva, Switzerland, 2012; p. 43.

128. Special Programme for Research and Training in Tropical Diseases (TDR), World Health Organization. Technical Handbook for Dengue Surveillance, Dengue Outbreak Prediction/Detection and Outbreak Response (Model Contingency Plan); World Health Organization: Geneva, Switzerland, 2016; p. 92.

129. Brady, O.J.; Smith, D.L.; Scott, T.W.; Hay, S.I. Dengue disease outbreak definitions are implicitly variable. Epidemics 2015, 11, 92-102. [CrossRef] [PubMed] 
130. Bowman, L.R.; Runge-Ranzinger, S.; McCall, P.J. Assessing the relationship between vector indices and dengue transmission: A systematic review of the evidence. PLoS Negl. Trop. Dis. 2014, 8, e2848. [CrossRef] [PubMed]

131. World Health Organization. World Malaria Report 2017; World Health Organization: Geneva, Switzerland, 2017; p. 196.

132. Bhatt, S.; Weiss, D.J.; Cameron, E.; Bisanzio, D.; Mappin, B.; Dalrymple, U.; Battle, K.; Moyes, C.L.; Henry, A.; Eckhoff, P.A.; et al. The effect of malaria control on Plasmodium falciparum in Africa between 2000 and 2015. Nature 2015, 526, 207-211. [CrossRef] [PubMed]

133. Ponlawat, A.; Harrington, L.C. Blood feeding patterns of Aedes aegypti and Aedes albopictus in Thailand. J. Med. Entomol. 2005, 42, 844-849. [CrossRef] [PubMed]

134. Scott, T.W.; Takken, W. Feeding strategies of anthropophilic mosquitoes result in increased risk of pathogen transmission. Trends Parasitol. 2012, 28, 114-121. [CrossRef] [PubMed]

135. Bonizzoni, M.; Gasperi, G.; Chen, X.; James, A.A. The invasive mosquito species Aedes albopictus: Current knowledge and future perspectives. Trends Parasitol. 2013, 29, 460-468. [CrossRef] [PubMed]

136. Chadee, D.D. Resting behaviour of Aedes aegypti in Trinidad: With evidence for the re-introduction of indoor residual spraying (IRS) for dengue control. Parasites Vectors 2013, 6, 255. [CrossRef] [PubMed]

137. Dzul-Manzanilla, F.; Ibarra-Lopez, J.; Bibiano Marin, W.; Martini-Jaimes, A.; Leyva, J.T.; Correa-Morales, F.; Huerta, H.; Manrique-Saide, P.; Vazquez-Prokopec, G.M. Indoor resting behavior of Aedes aegypti (Diptera: Culicidae) in Acapulco, Mexico. J. Med. Entomol. 2017, 54, 501-504. [PubMed]

138. Perich, M.J.; Davila, G.; Turner, A.; Garcia, A.; Nelson, M. Behavior of resting Aedes aegypti (Culicidae: Diptera) and its relation to ultra-low volume adulticide efficacy in Panama City, Panama. J. Med. Entomol. 2000, 37, 541-546. [CrossRef] [PubMed]

139. Paredes-Esquivel, C.; Lenhart, A.; del Rio, R.; Leza, M.M.; Estrugo, M.; Chalco, E.; Casanova, W.; Miranda, M.A. The impact of indoor residual spraying of deltamethrin on dengue vector populations in the Peruvian Amazon. Acta Trop. 2016, 154, 139-144. [CrossRef] [PubMed]

140. Vazquez-Prokopec, G.M.; Medina-Barreiro, A.; Che-Mendoza, A.; Dzul-Manzanilla, F.; Correa-Morales, F.; Guillermo-May, G.; Bibiano-Marin, W.; Uc-Puc, V.; Geded-Moreno, E.; Vadillo-Sanchez, J.; et al. Deltamethrin resistance in Aedes aegypti results in treatment failure in Merida, Mexico. PLoS Negl. Trop. Dis. 2017, 11, e0005656. [CrossRef] [PubMed]

141. Vazquez-Prokopec, G.M.; Montgomery, B.L.; Horne, P.; Clennon, J.A.; Ritchie, S.A. Combining contact tracing with targeted indoor residual spraying significantly reduces dengue transmission. Sci. Adv. 2017, 3, e1602024. [CrossRef] [PubMed]

142. Kigozi, R.; Baxi, S.M.; Gasasira, A.; Sserwanga, A.; Kakeeto, S.; Nasr, S.; Rubahika, D.; Dissanayake, G.; Kamya, M.R.; Filler, S.; et al. Indoor residual spraying of insecticide and malaria morbidity in a high transmission intensity area of Uganda. PLoS ONE 2012, 7, e42857. [CrossRef] [PubMed]

143. Kirby, M.J.; Ameh, D.; Bottomley, C.; Green, C.; Jawara, M.; Milligan, P.J.; Snell, P.C.; Conway, D.J.; Lindsay, S.W. Effect of two different house screening interventions on exposure to malaria vectors and on anaemia in children in The Gambia: A randomised controlled trial. Lancet 2009, 374, 998-1009. [CrossRef]

144. Tusting, L.S.; Ippolito, M.M.; Willey, B.A.; Kleinschmidt, I.; Dorsey, G.; Gosling, R.D.; Lindsay, S.W. The evidence for improving housing to reduce malaria: A systematic review and meta-analysis. Malar. J. 2015, 14, 209. [CrossRef] [PubMed]

145. Wanzirah, H.; Tusting, L.S.; Arinaitwe, E.; Katureebe, A.; Maxwell, K.; Rek, J.; Bottomley, C.; Staedke, S.G.; Kamya, M.; Dorsey, G.; et al. Mind the gap: House structure and the risk of malaria in Uganda. PLoS ONE 2015, 10, e0117396. [CrossRef] [PubMed]

146. Tusting, L.S.; Thwing, J.; Sinclair, D.; Fillinger, U.; Gimnig, J.; Bonner, K.E.; Bottomley, C.; Lindsay, S.W. Mosquito larval source management for controlling malaria. Cochrane Database Syst. Rev. 2013. [CrossRef] [PubMed]

147. Abad-Franch, F.; Zamora-Perea, E.; Luz, S.L. Mosquito-disseminated insecticide for citywide vector control and its potential to block arbovirus epidemics: Entomological observations and modeling results from Amazonian Brazil. PLoS Med. 2017, 14, e1002213. [CrossRef] [PubMed]

148. Boyce, R.; Lenhart, A.; Kroeger, A.; Velayudhan, R.; Roberts, B.; Horstick, O. Bacillus thuringiensis israelensis (Bti) for the control of dengue vectors: Systematic literature review. Trop. Med. Int. Health 2013, 18, 564-577. [CrossRef] [PubMed] 
149. Geissbuhler, Y.; Kannady, K.; Chaki, P.P.; Emidi, B.; Govella, N.J.; Mayagaya, V.; Kiama, M.; Mtasiwa, D.; Mshinda, H.; Lindsay, S.W.; et al. Microbial larvicide application by a large-scale, community-based program reduces malaria infection prevalence in urban Dar es Salaam, Tanzania. PLoS ONE 2009, 4, e5107. [CrossRef] [PubMed]

150. Mbare, O.; Lindsay, S.W.; Fillinger, U. Dose-response tests and semi-field evaluation of lethal and sub-lethal effects of slow release pyriproxyfen granules (Sumilarv ${ }^{\circledR} 0.5 \mathrm{G}$ ) for the control of the malaria vectors Anopheles gambiae sensu lato. Malar. J. 2013, 12, 94. [CrossRef] [PubMed]

151. Sangoro, O.; Turner, E.; Simfukwe, E.; Miller, J.E.; Moore, S.J. A cluster-randomized controlled trial to assess the effectiveness of using $15 \%$ DEET topical repellent with long-lasting insecticidal nets (LLINs) compared to a placebo lotion on malaria transmission. Malar. J. 2014, 13, 324. [CrossRef] [PubMed]

152. Sluydts, V.; Durnez, L.; Heng, S.; Gryseels, C.; Canier, L.; Kim, S.; Van Roey, K.; Kerkhof, K.; Khim, N.; Mao, S.; et al. Efficacy of topical mosquito repellent (picaridin) plus long-lasting insecticidal nets versus long-lasting insecticidal nets alone for control of malaria: A cluster randomised controlled trial. Lancet Infect. Dis. 2016, 16, 1169-1177. [CrossRef]

153. Wilson, A.L.; Chen-Hussey, V.; Logan, J.G.; Lindsay, S.W. Are topical insect repellents effective against malaria in endemic populations? A systematic review and meta-analysis. Malar. J. 2014, 13, 446. [CrossRef] [PubMed]

154. Horstmann, S.; Sonneck, R. Contact bioassays with phenoxybenzyl and tetrafluorobenzyl pyrethroids against target-site and metabolic resistant mosquitoes. PLoS ONE 2016, 11, e0149738. [CrossRef] [PubMed]

155. Ogoma, S.B.; Mmando, A.S.; Swai, J.K.; Horstmann, S.; Malone, D.; Killeen, G.F. A low technology emanator treated with the volatile pyrethroid transfluthrin confers long term protection against outdoor biting vectors of lymphatic filariasis, arboviruses and malaria. PLoS Negl. Trop. Dis. 2017, 11, e0005455. [CrossRef] [PubMed]

156. Fiorenzano, J.M.; Koehler, P.G.; Xue, R.D. Attractive toxic sugar bait (ATSB) for control of mosquitoes and its impact on non-target organisms: A review. Int. J. Environ. Res. Public Health 2017, 14, 398. [CrossRef] [PubMed]

157. World Health Organization. Global Vector Control Response 2017-2030; World Health Organization: Geneva, Switzerland, 2017; p. 53.

158. Golding, N.; Wilson, A.L.; Moyes, C.L.; Cano, J.; Pigott, D.M.; Velayudhan, R.; Brooker, S.J.; Smith, D.L.; Hay, S.I.; Lindsay, S.W. Integrating vector control across diseases. BMC Med. 2015, 13, 249. [CrossRef] [PubMed]

159. Mouchet, J.; Pichon, G.; Gayral, P.; Hamon, J. Sensitivity of and resistance to insecticides of Aedes aegypti in West Africa and methods of control of the vector. Bull. World Health Organ. 1971, 45, 394-404. [PubMed]

160. World Health Organization. Test Procedures for Insecticide Resistance Monitoring in Malaria Vectors, Bio-Efficacy and Persistence of Insecticides on Treated Surfaces; World Health Organization: Geneva, Switzerland, 1998.

161. Mazzarri, M.B.; Georghiou, G.P. Characterization of resistance to organophosphate, carbamate, and pyrethroid insecticides in field populations of Aedes aegypti from Venezuela. J. Am. Mosq. Control Assoc. 1995, 11, 315-322. [PubMed]

162. Seixas, G.; Grigoraki, L.; Weetman, D.; Vicente, J.L.; Silva, A.C.; Pinto, J.; Vontas, J.; Sousa, C.A. Insecticide resistance is mediated by multiple mechanisms in recently introduced Aedes aegypti from Madeira Island (Portugal). PLoS Negl. Trop. Dis. 2017, 11, e0005799. [CrossRef] [PubMed]

163. Rocha, H.D.; Paiva, M.H.; Silva, N.M.; de Araujo, A.P.; Camacho Ddos, R.; Moura, A.J.; Gomez, L.F.; Ayres, C.F.; Santos, M.A. Susceptibility profile of Aedes aegypti from Santiago Island, Cabo Verde, to insecticides. Acta Trop. 2015, 152, 66-73. [CrossRef] [PubMed]

164. Suzuki, T.; Osei, J.H.; Sasaki, A.; Adimazoya, M.; Appawu, M.; Boakye, D.; Ohta, N.; Dadzie, S. Risk of transmission of viral haemorrhagic fevers and the insecticide susceptibility status of Aedes aegypti (Linnaeus) in some sites in Accra, Ghana. Ghana Med. J. 2016, 50, 136-141. [PubMed]

165. Mathias, L.; Baraka, V.; Philbert, A.; Innocent, E.; Francis, F.; Nkwengulila, G.; Kweka, E.J. Habitat productivity and pyrethroid susceptibility status of Aedes aegypti mosquitoes in Dar es Salaam, Tanzania. Infect. Dis. Poverty 2017, 6, 102. [CrossRef] [PubMed]

166. Du, Y.; Nomura, Y.; Satar, G.; Hu, Z.; Nauen, R.; He, S.Y.; Zhorov, B.S.; Dong, K. Molecular evidence for dual pyrethroid-receptor sites on a mosquito sodium channel. Proc. Natl. Acad. Sci. USA 2013, 110, 11785-11790. [CrossRef] [PubMed] 
167. Hirata, K.; Komagata, O.; Itokawa, K.; Yamamoto, A.; Tomita, T.; Kasai, S. A single crossing-over event in voltage-sensitive $\mathrm{Na}^{+}$channel genes may cause critical failure of dengue mosquito control by insecticides. PLoS Negl. Trop. Dis. 2014, 8, e3085. [CrossRef] [PubMed]

168. Stevenson, B.J.; Pignatelli, P.; Nikou, D.; Paine, M.J. Pinpointing p450s associated with pyrethroid metabolism in the dengue vector, Aedes aegypti: Developing new tools to combat insecticide resistance. PLoS Negl. Trop. Dis. 2012, 6, e1595. [CrossRef] [PubMed]

169. Kasai, S.; Komagata, O.; Itokawa, K.; Shono, T.; Ng, L.C.; Kobayashi, M.; Tomita, T. Mechanisms of pyrethroid resistance in the dengue mosquito vector, Aedes aegypti: Target site insensitivity, penetration, and metabolism. PLoS Negl. Trop. Dis. 2014, 8, e2948. [CrossRef] [PubMed]

170. Grigoraki, L.; Pipini, D.; Labbe, P.; Chaskopoulou, A.; Weill, M.; Vontas, J. Carboxylesterase gene amplifications associated with insecticide resistance in Aedes albopictus: Geographical distribution and evolutionary origin. PLoS Negl. Trop. Dis. 2017, 11, e0005533. [CrossRef] [PubMed]

(C) 2018 by the authors. Licensee MDPI, Basel, Switzerland. This article is an open access article distributed under the terms and conditions of the Creative Commons Attribution (CC BY) license (http://creativecommons.org/licenses/by/4.0/). 